\title{
Patterns for Populus spp. Stand Biomass in Gradients of Winter Temperature and Precipitation of Eurasia
}

\author{
Vladimir Andreevich Usoltsev 1,2,3, Baozhang Chen 1,4,*, Seyed Omid Reza Shobairi ${ }^{1,2}$, \\ Ivan Stepanovich Tsepordey ${ }^{3}$, Viktor Petrovich Chasovskikh ${ }^{2}$ and Shoaib Ahmad Anees ${ }^{5}$ \\ 1 School of Remote Sensing and Geomatics Engineering, Nanjing University of Information Science and \\ Technology, Nanjing 210000, China; usoltsev50@mail.ru (V.A.U.); general@usfeu.ru or \\ Omidshobeyri214@gmail.com (S.O.R.S.) \\ 2 Ural State Forest Engineering University, Faculty of Forestry, Sibirskiy Trakt, 37, \\ 620100 Yekaterinburg, Russia; u2007u@ya.ru \\ 3 Botanical Garden of Ural Branch of RAS, Department of Forest Productivity, ul. 8 Marta, 202a, \\ 620144 Yekaterinburg, Russia; common@botgard.uran.ru \\ 4 LREIS, Institute of Geographic Sciences \& Nature Resources Research Chinese Academy Sciences (CAS) 11A \\ Datun Rd, Beijing 100101, China \\ 5 Beijing Key Laboratory of Precision Forestry, Forestry College, Beijing Forestry University, \\ Beijing 100083, China; saanees@bjfu.edu.cn \\ * Correspondence: Baozhang.chen@nuist.edu.cn or Baozhang.Chen@igsnrr.ac.cn
}

Received: 7 July 2020; Accepted: 13 August 2020; Published: 19 August 2020

\begin{abstract}
Based on a generated database of 413 sample plots, with definitions of stand biomass of the genus Populus spp. in Eurasia, from France to Japan and southern China, statistically significant changes in the structure of forest stand biomass were found, with shifts in winter temperatures and average annual precipitation. When analyzing the reaction of the structure of the biomass of the genus Populus to temperature and precipitation in their transcontinental gradients, a clearly expressed positive relationship of all components of the biomass with the temperature in January is visible. Their relationship with precipitation is less clear; in warm climate zones, when precipitation increases, the biomass of all wood components decreases intensively, and in cold climate zones, this decrease is less pronounced. The foliage biomass does not increase when precipitation decreases, as is typical for wood components, but decreases. This can be explained by the specifics of the functioning of the assimilation apparatus, namely its transpiration activity when warming, and the corresponding increase in transpiration, which requires an increase in the influx of assimilates into the foliage, and the desiccation of the climate that reduces this influx of assimilates. Comparison of the obtained patterns with previously published results for other species from Eurasia showed partial or complete discrepancies, the causes of which require special physiological studies. The results obtained can be useful in the management of biosphere functions of forests, which is important in the implementation of climate stabilization measures, as well as in the validation of the results of simulation experiments to assess the carbon-deposition capacity of forests.
\end{abstract}

Keywords: genus Populus spp.; regression models; stand biomass; biomass structure; climate change; average January temperature; average annual precipitation 


\section{Introduction}

Active human economic activity has led to significant global changes in the functioning of the biosphere, and the observed climate warming has had a significant impact on the vegetation cover of the planet [1,2]. If earlier, the problems of assessing climate impacts on vegetation had a regional character [3], then in recent decades it has become clear that the problem has reached a global, general planetary level, and largely determines the future fate of human civilization [4,5]. Mapping the distribution of net primary production (NPP) over the surface of the planet, by extrapolating empirical NPP data obtained from forest sample plots to large areas of biomes [6,7] or to latitude gradients [8,9] does not allow for making any predictions of changes in the climate-NPP system. The same can be said about the common planetary patterns of distribution of NPP harvest data by gradients of average temperatures and precipitation [10].

Due to current climate changes, priority is given to changing the biomass and NPP of forest ecosystems under the influence of average temperatures and precipitation. Similar studies are performed at both a regional [11-13] and transcontinental [14,15] levels. Their implementation, especially in the latter case, is one of the problems that constitute the subject of biogeography [16]. The forest, as we know, is a geographical phenomenon [17], and in view of the topic indicated in the title of this work, it is important for us to identify the geographical aspects of the biomass of forest ecosystems, i.e., to make a choice in favor of those geographical characteristics that determine the distribution of forest biomass on the territory of a particular continent.

However, the biomass of a stand represented by a particular tree species is primarily determined by its age and morphological (taxation) structure, i.e., a set of characteristics such as age, mean height, mean diameter at breast height, the basal area, and the volume stock, which are interrelated. The problem of multicollinearity arises in empirical modeling of biomass. One of the solutions to the problem is to harmonize the system by constructing recursive (recurrent, related) equations, in which the dependent variable of the previous equation is included as one of the independent variables of the subsequent one [18]. This approach provides a multivariate conditionality of factors that provide flexibility and universality of the regression system describing the dynamics of biomass of stands.

To account for the geographical effect in this recursive system, each equation of the system must be supplemented with corresponding regressors. One possible option is to introduce dummy variables [18] that encode the regional affiliation of the harvest data $[11,18,19]$ as one of the methods for model harmonization [20]. The disadvantage of such equations is that they only take into account the geographical shifts of the desired variables by the value of the interception term. It is assumed that the regression coefficients in such cases are unchanged by region, which is not true. The second option is to include indices of natural zoning and continentality of climate in the equations of the system [21], using the basis that changes in vegetation cover occur both in the latitudinal direction due to changes in the PhAR [22], and in the meridional direction due to changes in the continentality of climate [23]. Therefore, models of the phytomass of trees and plantings have been developed, including their mass-forming indices as independent variables, as well as indices of natural zoning and climate continentality [21]. However, such models do not provide an answer to the question of in which direction the biomass structure of a particular tree species may change with the expected change in air temperature or annual precipitation. The use of evapotranspiration as a combined index in the assessment of tree production is futile, since it explains only $24 \%$ of its variability compared to $42 \%$, which provides the relation to mean annual precipitation, and compared to $31 \%$, which provides the relation to mean annual temperature [24]. It is assumed that orography, soil water balance, $\mathrm{PhAR}$, and climate continentality are indirectly reflected in the territorial features of temperatures and precipitation. 
Studies of forest stand biomass at the transcontinental level, performed for five species from Eurasia, showed that changes in their biomass due to temperatures and precipitation are species-specific, i.e., they differ between species in the total biomass [25]. If we adhere to the concept of species-specific responses of forest biomass to changes in the main climatic characteristics, then when we reach the transcontinental level, we are faced with the obvious fact that no species grows throughout the continent, precisely because of regional climate differences. Moving from refuges under the influence of geological processes and climate changes, a particular species adapted to changing environmental conditions, forming a series of vicariate species within the genus [26,27]. This gives grounds for analyzing the response of tree species to changes in climate characteristics, to combine them into one climate-dependent set within the entire genus, since differences in ecological and physiological properties of different species of the genus, for example, Populus tremula vs. P. trichocarpa vs. P. pruinosa are derived from regional climatic features.

Eurasia is the largest continental area on Earth, located primarily in the Northern and Eastern Hemispheres, it is bordered by the Atlantic Ocean to the west, the Pacific Ocean to the east, the Arctic Ocean to the north, and by Africa, the Mediterranean Sea, and the Indian Ocean to the south. Eurasia covers around 55,000,000 square kilometers (21,000,000 sq mi), or around 36.2\% of the Earth's total land area. The landmass contains well over 5 billion people, equating to approximately $70 \%$ of the human population. The unique size and complexity of the natural conditions differentiate Eurasia from the rest of continents. No continent has such an original history of paleogeographic development. Structural differences are reflected in the features of the morphological structure. In the territory of Eurasia there are the highest mountain systems, vast highlands, plateaus, and plains. Climatic and landscape conditions are no less diverse. Here you can trace all the geographical zones that are characteristic of the land of the globe from the icy deserts in the North to the humid equatorial forests in the South [28].

In our work, we made the first attempt to study transcontinental trends in the structure of biomass of the genus Populus spp., formed under the influence of geographically distributed temperatures and precipitation in the territory of Eurasia. Across the Northern Hemisphere, this genus plays a disproportionately important role in promoting biodiversity and sequestering carbon. It is illustrative of efforts to move beyond single-species conservation worldwide. The genus Populus is valued for many reasons, but one highlights their potential as key contributors to regional and global biodiversity [29]. A tremendous need for paper, cardboard, and board materials open almost unlimited opportunities for the economic use of this genus' wood. By density and cellulose content, poplar wood does not come up short compared to the coniferous species. Despite the slightly shorter wood fiber of poplar in comparison to spruce, modern technologies make the first class production of paper, cardboard, and wood board materials out of this "disgraced" species possible. Today, however, the genus Populus is an example of a particularly evident disparity, between the potential organic matter production in plantations, and its actual implementation in the boreal natural forests [30].

\section{Objects of Research}

To analyze geographical patterns of biomass distribution in Eurasian forests formed by stands of the genus Populus spp., from the author's database of eight thousand sample plots [31], the materials of 413 determinations with the data of the biomass structure were used. These biomass data were presented in different components (stems, branches, foliage, and roots). The distribution of sample plots with biomass data of the genus Populus spp. on the map-scheme of Eurasia is shown in Figure 1, and according to tree species and countries, in Table 1. 


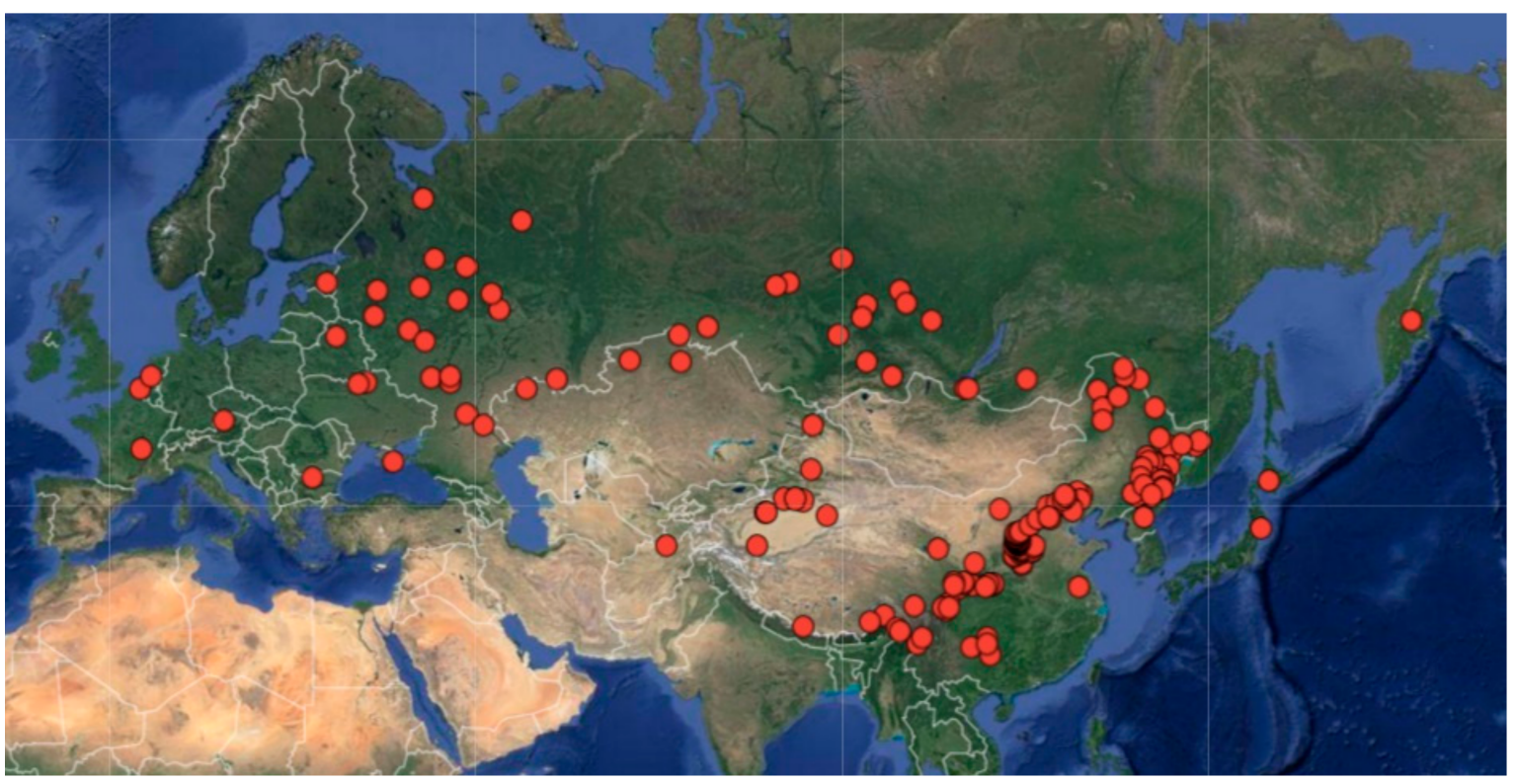

Figure 1. Allocation of sample plots with biomass ( $\mathrm{t} / \mathrm{ha}$ ) determinations of 413 Populus forest stands in the territory of Eurasia.

Table 1. Distribution of plots with determinations of Populus biomass ( $\mathrm{t} / \mathrm{ha}$ ) by species and countries.

\begin{tabular}{cccc}
\hline Species & Botanical Name & Country & Plot Quantity \\
\hline Quaking aspen & Populus tremula L. & $\begin{array}{c}\text { Russia, Ukraine, Kazakhstan, } \\
\text { Estonia, Belarus }\end{array}$ & 188 \\
\hline David's aspen & P. davidiana Dode & China, Japan & 129 \\
\hline Californian poplar & $\begin{array}{c}\text { P. trichocarpa Torr. \& } \\
\text { A.Gray ex Hook. }\end{array}$ & $\begin{array}{c}\text { France, Austria, Belgium, } \\
\text { Netherlands }\end{array}$ & 37 \\
\hline Poplar larrity & P. laurifolia Ledeb. & Russia & 12 \\
\hline White poplar & P. alba Ledeb. & Russia, Kazakhstan & 10 \\
\hline Poplar «Robusta» & Populus $\times$ euroamericana & Ukraine & 10 \\
\hline Asiatic poplar & P. euphratica Olivier & China & 9 \\
\hline Hybrid & Populus hybrid & Japan & 8 \\
\hline Poplar berry-bearing & $\begin{array}{c}\text { P. deltoids W. Bartram ex } \\
\text { Humphry Marshall }\end{array}$ & China & 6 \\
\hline Black poplar & P. nigra L. & Russia & 2 \\
\hline Bahala poplar & $\begin{array}{c}\text { Populus } \times \text { bachelieri } \\
\text { Solemacher }\end{array}$ & Bulgaria & 1 \\
\hline Ploomy poplar & P. pruinosa Schrenk & Tajikistan & 1 \\
\hline
\end{tabular}

\section{Methods}

As the plots for estimating biomass of forest stands were usually established in typical 'background' habitats, which were representative in relation to this type of plant communities, one can make on their basis a preliminary geographical analysis of biomass gradients of Populus forests. For an analytical description of the geographic distribution patterns of the biomass productivity of forest cover, one must choose the geographical characteristics of the territory of Eurasia that can be expressed by quantity and measure. 
The actual values of the biomass of 413 stands of the genus Populus (see Figure 1), based on the known coordinates of the sample plots established, we superimposed on the maps of winter (January) temperatures and average annual precipitation distribution [32], and related them to the isolines of the mentioned indices on the maps. In our case, the schematic map of the isolines of mean January temperature, rather than that of the mean annual temperature, was used. With an inter-annual time step, the predominant influence of summer temperature is quite normal [33]. However, against the background of long-term climatic shifts for decades, the prevailing influence is acquired by winter temperatures [34,35]. For example, Toromani and Bojaxhi [36] write: "Earlier studies has shown that phytosynthesis is possible for Abies alba in winter, where high temperatures could play an important role in improving carbohydrate storage and growth at following year. For species grown under a Mediterranen climate high temperatures and low precipitation during growing season may cause water stress, which is the main limiting factor for tree growth".

We should keep in mind that winter temperatures in the Northern Hemisphere have increased faster than summer ones during the 20th century [37-39]. In terms of regression analysis, a weak temporal trend of summer temperatures compared to a steep trend of winter ones, means a smaller regression slope and a worse ratio of residual variance to the total variance explained by this regression. Obviously, taking the mean winter temperature as one of the independent variables, we get a more reliable dependence having the higher predictive ability.

Then, the compiled matrix of harvest data (Table 2) were subjected to the common regression analysis.

Table 2. A fragment of the original matrix of experimental data *.

\begin{tabular}{|c|c|c|c|c|c|c|c|c|c|c|}
\hline \multirow{2}{*}{ A } & \multirow{2}{*}{$\mathbf{N}$} & \multirow{2}{*}{$\mathbf{V}$} & \multicolumn{6}{|c|}{$\mathbf{P}_{\mathbf{i}}$} & \multirow{2}{*}{$\mathrm{Tm}$} & \multirow{2}{*}{ PRm } \\
\hline & & & $\mathbf{P}_{\mathrm{s}}$ & $\mathbf{P}_{\mathbf{b}}$ & $\mathbf{P}_{\mathbf{f}}$ & $\mathbf{P}_{\mathbf{a}}$ & $\mathbf{P}_{\mathbf{r}}$ & $\mathbf{P}_{\mathrm{t}}$ & & \\
\hline 40 & 0.790 & 208 & 89 & 5.5 & 2.40 & 98.0 & 21.6 & 119.6 & -7 & 570 \\
\hline 21 & 0.278 & 218 & 99.8 & 20.7 & 4.19 & 129.7 & 29.2 & 158.9 & -3 & 570 \\
\hline 12 & 12.54 & 62.5 & 34.8 & 4.45 & 1.91 & 41.2 & 15.0 & 56.2 & -13 & 290 \\
\hline 22 & 4.550 & 30 & 16.1 & 4.24 & 0.80 & 21.1 & 6.0 & 27.1 & -13 & 290 \\
\hline 49 & 0.650 & 284 & 113 & 22.5 & 3.07 & 138.6 & 57.0 & 195.6 & -20 & 317 \\
\hline 41 & 0.526 & 192 & 76.0 & 22.2 & 2.40 & 100.6 & 55.0 & 155.6 & -18 & 250 \\
\hline 78 & 0.518 & 200 & 88.83 & 28.37 & 4.99 & 127.7 & 38.79 & 166.5 & -15 & 570 \\
\hline 45 & 0.500 & 105 & 49.62 & 10.92 & 4.52 & 67.56 & 8.58 & 76.14 & -26 & 570 \\
\hline 78 & 0.666 & 185 & 103.1 & 45.44 & 8.75 & 163.9 & 37.8 & 201.7 & -15 & 570 \\
\hline 27 & 2.935 & 142 & 84.29 & 17.56 & 7.01 & 114.0 & 42.73 & 156.7 & -9 & 820 \\
\hline 68 & 1.244 & 223 & 102.4 & 22.44 & 7.43 & 138.5 & 51.47 & 190.0 & -15 & 570 \\
\hline 25 & 4.066 & 122 & 73.51 & 11.31 & 5.89 & 95.04 & 36.6 & 131.6 & -15 & 570 \\
\hline 40 & 1.062 & 224 & 99.81 & 32.82 & 7.69 & 146.6 & 45.47 & 192.1 & -15 & 570 \\
\hline 34 & 1.595 & 182 & 95.77 & 13.15 & 7.91 & 122.6 & 52.18 & 174.8 & -10 & 444 \\
\hline 50 & 1.510 & 163 & 75.11 & 22.44 & 6.21 & 108.4 & 34.26 & 142.7 & -25 & 444 \\
\hline 28 & 7.32 & 129 & 73.0 & 11.40 & 2.00 & 89.93 & 17.2 & 107.1 & -15 & 570 \\
\hline 37 & 2.913 & 153 & 86.65 & 18.56 & 6.27 & 116.7 & 41.79 & 158.5 & -15 & 570 \\
\hline 69 & 0.811 & 284 & 110.9 & 17.20 & 7.62 & 142.2 & 56.36 & 198.6 & -26 & 444 \\
\hline 58 & 1.188 & 124 & 61.47 & 16.79 & 3.66 & 85.63 & 27.24 & 112.9 & -26 & 444 \\
\hline 79 & 0.403 & 163 & 68.75 & 18.91 & 3.66 & 95.43 & 29.6 & 125.0 & -26 & 444 \\
\hline 38 & 4.255 & 121 & 73.56 & 11.79 & 6.19 & 95.95 & 38.21 & 134.2 & -15 & 570 \\
\hline 68 & 1.822 & 234 & 117.3 & 30.29 & 7.23 & 162.0 & 54.8 & 216.8 & -26 & 444 \\
\hline 29 & 2.000 & 61 & 34.42 & 16.31 & 2.77 & 55.88 & 16.57 & 72.45 & -5 & 826 \\
\hline 39 & 2.774 & 62 & 37.92 & 8.72 & 3.00 & 58.27 & 9.41 & 67.68 & -5 & 826 \\
\hline
\end{tabular}

* $A$ = stand age, $\mathrm{y} ; V=$ stem volume, $\mathrm{m}^{3} / \mathrm{ha} ; N=$ tree density, $1000 /$ ha; $i=$ index of biomass component: total wood storey $(t)$, aboveground wood storey $(a)$, underground wood storey, or roots $(r)$, stem over the bark $(s)$, foliage $(f)$, and branches $(b) ; P R m=$ mean annual precipitation, $\mathrm{mm} ; \mathrm{Tm}=$ mean January temperature, ${ }^{\circ} \mathrm{C}$. 
The basic principles of modelling and the results obtained by means of regression analysis should have an ecologic-geographical interpretation. The biological productivity of forests is dependent on climatic factors, but only as a first approximation, since there are ontogenetic, cenotic, edaphic, and other levels of its variability. Therefore, we included in the regression equations the independent variables explaining the variability of the dependent variable, expressing not only with climatic parameters but also with forest age, tree density, and stem volume.

As the mean January temperature in the northern part of Eurasia has negative values, the corresponding independent variable was modified to the form $(T m+50)$. Then, the technique of multiple regression analysis (http://www.statgraphics.com/for more information), according to three blocks of recursive equations, was used: two blocks of mass-forming indices, $N$ and $V$, and a single block of biomass $P_{i}$ (arrows show the sequence of calculations)

$$
\begin{gathered}
\ln N=\mathrm{a}_{0}+\mathrm{a}_{1}(\ln A)+\mathrm{a}_{2}[\ln (\operatorname{Tm}+50)]+\mathrm{a}_{3}(\ln P R m) \\
\ln V=\mathrm{a}_{0}+\mathrm{a}_{1}(\ln A)+\mathrm{a}_{2}(\ln N)+\mathrm{a}_{3}[\ln (\operatorname{Tm}+50)]+\mathrm{a}_{4}(\ln P R m) ; \\
\ln P_{i}=\mathrm{a}_{0}+\mathrm{a}_{1}(\ln A)+\mathrm{a}_{2}(\ln V)+\mathrm{a}_{3}(\ln N)+\mathrm{a}_{4}[\ln (T m+50)]+\mathrm{a}_{5}(\ln P R m)
\end{gathered}
$$

\section{Results and Discussion}

The results of the calculation of Equations (1)-(3) are listed in the Table 3. Only the variables that are significant at the level of probability of $\mathrm{P}_{95}$ and above are showed in this table. The equations were tabulated in the sequence illustrated by the arrows. The results of tabulating the models in the sequence of Equations (1)-(3) present the rather cumbersome table. We took from it the values of the component composition of the biomass of the Populus forests of the age of 50 years and built 3D-graphs

\begin{tabular}{|c|c|c|c|c|c|c|c|c|}
\hline $\begin{array}{l}\text { Dependent } \\
\text { Variables }\end{array}$ & \multicolumn{6}{|c|}{ Coefficients and Independent Variables } & $\operatorname{adj} R^{2 * *}$ & $\mathrm{SE} * * *$ \\
\hline $\ln (N)$ & 10.7307 & -1.2994 & - & - & -2.4045 & 0.4747 & 0.623 & 0.74 \\
\hline $\ln \left(P_{S}\right)$ & -1.8923 & 0.2068 & 0.9123 & 0.0646 & 0.0764 & 0.0811 & 0.963 & 0.17 \\
\hline $\ln \left(P_{b}\right)$ & -2.8796 & 0.2421 & 0.5520 & -0.0537 & 0.3792 & 0.0678 & 0.675 & 0.44 \\
\hline $\ln \left(P_{a}\right)$ & -1.2511 & 0.1782 & 0.8183 & 0.0463 & 0.0984 & 0.0960 & 0.955 & 0.17 \\
\hline $\ln \left(P_{t}\right)$ & -1.1022 & 0.0477 & 0.7969 & 0.0486 & 0.1467 & 0.1849 & 0.918 & 0.18 \\
\hline
\end{tabular}
of their dependence upon temperature and precipitation (Figure 2).

Table 3. Characteristics of biomass Equations (1) to (3).

* The constant corrected for logarithmic retransformation by [40]; ** adj $R^{2}=$ determination coefficient adjusted for the number of variables; $* * * S E=$ standard error of the equations.

When analyzing the reaction of the biomass structure of the genus Populus to temperature and precipitation in their transcontinental gradients, a clearly expressed unambiguous positive relationship of all components of the biomass with the average temperature of January is seen. Their relationship with precipitation is less clear; in warm climate zones $\left(\mathrm{Tm}=0{ }^{\circ} \mathrm{C}\right)$, when precipitation increases the biomass of all wood components decreases most intensively, and in cold climate zones $\left(\mathrm{Tm}=-40^{\circ} \mathrm{C}\right)$ this decrease is expressed to a much lesser extent. 

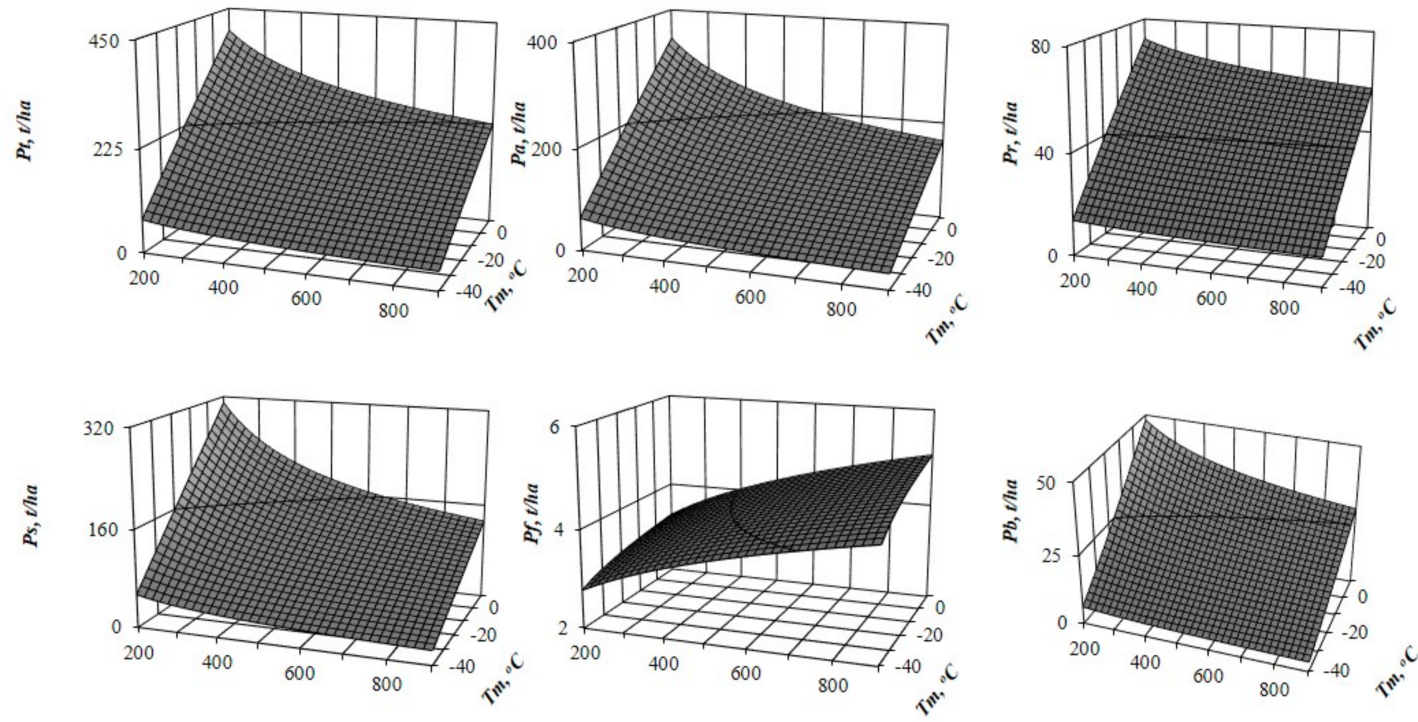

Figure 2. Dependence of Populus ecosystems of Eurasia upon the mean January temperature (Tm) and mean annual precipitation $(P R m)$. Abbreviations: $P t, P a, P s, P r, P f, P b$ are, respectively, biomass of: total wood storey, aboveground, stems (wood and bark), roots, foliage, and branches, $t / h a$.

It is interesting to compare the obtained patterns of changes in the total biomass of the genus Populus with previously published results for other forest-forming species of Eurasia, obtained using a similar methodology [25]. The increase in the total biomass of Populus during the transition from cold to warm regions was confirmed earlier for Larix spp., Picea spp., Abies spp., and Betula spp. However, the decrease in the total biomass as precipitation increases was confirmed only in larch, whereas in spruce, fir, and birch, the dependence is the opposite of that established for Populus. The specific pattern of the change in the total biomass was obtained for two-needled pines Pinus L.; its increase during the transition from cold to warm regions was recorded only in regions with heavy precipitation, and with the transition to water-deficit regions, the pattern changes to the opposite. If, in Populus and Larix, the decrease in total biomass with the transition from water-deficient to moisture-rich regions was observed in all thermal zones, then in two-needled pines (only in cold zones, and with the transition from cold to warm climatic zones) this negative trend changes to the opposite.

We can see that the reaction of foliage biomass with increasing precipitation does not decrease, as is typical for wood components, but increases (Figure 2). This is consistent with a similar situation observed in Russian Siberia with respect to forest cover [41], where with a warming climate and a simultaneous decrease in precipitation, the share of assimilation mass decreases, and the share of wood components increases. This is explained by the specifics of foliage functioning, namely, its transpiration activity when warming, and a corresponding increase in transpiration requires an increase in the influx of assimilates into the foliage, while the desiccation of the climate reduces this influx of assimilates due to a decrease in transpiration activity. Perhaps this phenomenon demonstrates the future scenario of acclimatization of trees to the ongoing warming and changes in the water balance of territories. However, in Canada's forests, a contradictory result was obtained. If the January temperature and humidity conditions of the growing season had a positive effect on the growth of Betula papyrifera Marsh. and the growth of Picea mariana Mill., then Populus tremuloides Michx. might be the least responsive species [42].

The patterns of biomass-amount change, under assumed changed climatic conditions (Figure 2), are hypothetical. They reflect long-term adaptive responses of forest stands to regional climatic conditions and do not take into account rapid trends of current environmental changes, which place serious constraints on the ability of forests to adapt to new climatic conditions [43-49]. Climate changes are manifested primarily in shifts in the phenology of a particular species, and are determined by the 
degree of species-specific phenotypic plasticity [50], which were not taken into account in our work, and require special study.

The law of limiting factors [51] works well in stationary conditions. With a rapid change in limiting factors (such as air temperature or precipitation), forest ecosystems are in a transitional (non-stationary) state, in which some factors that were not significant may come to the fore, and the end result may be determined by other limiting factors [52].

The main pool of biomass harvest data in Eurasia was obtained during the 1970s-1990s, and the climate maps used, cover the period of the late 1990s-early 2000s. Some discrepancy between the two time periods may cause some biases in the results obtained, but for such a small time difference in the used data, the inclusion of compensatory mechanisms or phenological shifts in forest communities is unlikely $[47,48]$.

\section{Conclusions}

Based on a database of 413 sample plots, with definitions of forest biomass of the genus Populus spp. in Eurasia, in the territory from France to the South of China and Japan, a statistically significant increase in stem, aboveground, and underground biomass was found with an increase in winter temperatures and a decrease in precipitation, especially in warm climate regions. In contrast to the woody components of biomass, the mass of foliage, while increasing with warming, simultaneously decreases with a decrease in precipitation, which is due to the specifics of the functioning of foliage, namely, its transpiration activity.

Comparison of the results obtained for Populus showed that the regularities of Populus are repeated only in Larix, and in other species, only partially. In our work, we can only state the species-specificity of the reaction of various Eurasian species to changes in temperature and precipitation, but explaining this specificity at the level of physiological processes is the task of the future.

The results obtained can be useful in the management of biosphere functions of forests, which is important in the implementation of climate stabilization measures, as well as in the validation of the results of simulation experiments to assess the carbon-deposition capacity of forests. They also provide a preliminary idea of possible shifts in forest biological productivity indicators under the influence of climate change.

Author Contributions: V.A.U.-analyzed the data, mathematical processing, prepared the manuscript; B.C. contributed to the conceptualization of ideas, the methodology and the review of the manuscript; S.O.R.S. - designed the study and the review of the manuscript; I.S.T.-mathematical processing, design; V.P.C.—-mathematical adjustment; S.A.A.—spelling edit. All authors have read and agreed to the published version of the manuscript.

Funding: This research was funded by the National Key R\&D Program of China (2018YFA0606001,2017YFA0604302, 2017YFC0503904,and 2017YFA0604301), an international partnership program of Chinese Academy of Sciences (Grant 131A11KYSB20170025), a research project funded by the State Key Laboratory of Resources and Environmental Information System (O88RA901YA) and a project funded by the National Natural Science Foundation of China (41771114 \& 41977404).

Conflicts of Interest: The authors declare no conflict of interest.

\section{References}

1. Halofsky, J.S.; Conklin, D.R.; Donato, D.C.; Halofsky, J.E.; Kim, J.B. Climate change, wildfire, and vegetation shifts in a high-inertia forest landscape: Western Washington, U.S.A. PLoS ONE 2018, 13, e0209490. [CrossRef] [PubMed]

2. Kosanic, A.; Anderson, K.; Harrison, S.; Turkington, T.; Bennie, J. Changes in the geographical distribution of plant species and climatic variables on the West Cornwall peninsula (South West UK). PLoS ONE 2018, 13, e0191021. [CrossRef] [PubMed]

3. Glebov, F.; Litvinenko, V. The dynamics of tree ring width in relation to meteorological indices in different types of wetland forests. Lesovedenie 1976, 4, 56-62. 
4. Tarko, A. Antropogennye Izmeneniya Global'nykh Biosfernykh Protsessov [Anthropogenic Changes of Global Biosphere Processes]; Fizmatlit: Moscow, Russia, 2005.

5. Behrensmeyer, A.K. ATMOSPHERE: Climate Change and Human Evolution. Science 2006, 311, 476-478. [CrossRef]

6. Bazilevich, N.; Rodin, L. Schematic Maps of Productivity and Biological Turnover of Elements in the main Types of Land vegetation. Izvestiya Vsesoyuznogo Geograficheskogo Obshchestva 1967, 99, 190-194.

7. Rodin, L.E.; Bazilevich, N. Production and Mineral Cycling in Terrestrial Vegetation; Oliver \& Boyd: Edinburgh/London, UK, 1967.

8. Anderson, K.J.; Allen, A.P.; Gillooly, J.F.; Brown, J.H. Temperature-dependence of biomass accumulation rates during secondary succession. Ecol. Lett. 2006, 9, 673-682. [CrossRef]

9. Huston, M.A.; Wolverton, S. The global distribution of net primary production: resolving the paradox. Ecol. Monogr. 2009, 79, 343-377. [CrossRef]

10. Lieth, H. Modeling the Primary Productivity of the World. Ecol. Stud. 1975, 4, 237-263.

11. Fu, L.; Sun, W.; Wang, G. A climate-sensitive aboveground biomass model for three larch species in northeastern and northern China. Trees 2016, 31, 557-573. [CrossRef]

12. Forrester, D.I.; Tachauer, I.; Annighoefer, P.; Barbeito, I.; Pretzsch, H.; Ruiz-Peinado, R.; Stark, H.; Vacchiano, G.; Zlatanov, T.; Chakraborty, T.; et al. Generalized biomass and leaf area allometric equations for European tree species incorporating stand structure, tree age and climate. For. Ecol. Manag. 2017, 396, 160-175. [CrossRef]

13. Zeng, W.; Duo, H.; Lei, X.; Chen, X.; Wang, X.; Pu, Y.; Zou, W. Individual tree biomass equations and growth models sensitive to climate variables for Larix spp. in China. Eur. J. For. Res. 2017, 136, 233-249. [CrossRef]

14. Usoltsev, V.A.; Merganičová, K.; Konôpka, B.; Osmirko, A.A.; Tsepordey, I.S.; Chasovskikh, V.P. Fir (Abies spp.) stand biomass additive model for Eurasia sensitive to winter temperature and annual precipitation. Central Eur. For. J. 2019, 65, 166-179. [CrossRef]

15. Hubau, W.; Lewis, S.L.; Phillips, O.L.; Affum-Baffoe, K.; Beeckman, H.; Cuní-Sanchez, A.; Daniels, A.K.; Ewango, C.E.N.; Fauset, S.; Mukinzi, J.M.; et al. Asynchronous carbon sink saturation in African and Amazonian tropical forests. Nature 2020, 579, 80-87. [CrossRef] [PubMed]

16. Lomolino, M.V.; Riddle, B.R.; Brown, J.H. Biogeography, 3rd ed.; Sinauer Associates Inc.: Sunderland, MA, USA, 2006.

17. Morozov, G.F. The Theory of Forest Stand Types; Selkolkhozgiz: Moscow-Leningrad, Russia, 1931.

18. Draper, N.; Smith, H. Applied Regression Analysis; Wiley: New York, NY, USA, 1966.

19. Zeng, W. Developing Tree Biomass Models for Eight Major Tree Species in China. In Biomass Volume Estimation and Valorization for Energy; IntechOpen: London, UK, 2017; pp. 3-21. [CrossRef]

20. Jacobs, M.W.; Cunia, T. Use of dummy variables to harmonize tree biomass tables. Can. J. For. Res. 1980, 10, 483-490. [CrossRef]

21. Usoltsev, V.A.; Shobairi, S.O.; Tsepordey, I.S.; Chasovskikh, V.P. Additive Allometric model of Populus sp. Single-Tree Biomass as a Basis of Regional Taxation Standards for Eurasia. Indian For. 2019, 145, 625-630.

22. Grigoriev, A.; Budyko, M. The periodicity law of geographic zonality. Doklady Akademii Nauk SSSR 1956, 110, 129-132.

23. Komarov, V. Meridional zonality of organisms. In Proceedings of the 1st All-Russian Congress of Russian Botanists in Petrograd, Leningrad, Russia, 16 September 1921.

24. Ni, J.; Zhang, X.-S.; Scurlock, J.M. Synthesis and analysis of biomass and net primary productivity in Chinese forests. Ann. For. Sci. 2001, 58, 351-384. [CrossRef]

25. Usoltsev, V.A.; Tsepordey, I.S.; Osmirko, A.A. Biological productivity of Eurasian forests due to temperature and precipitation. In Proceedings of the Forest Ecosystems of Boreal Zone: Biodiversity, Bioeconomy, Ecological Risks, All-Russian Conference with International Participation. Krasnoyarsk, Russia, 26-31 August 2019; pp. 458-460. (In Russian with English title, summary and contents)

26. Hultén, E.; Lehre, J. Outline of the History of Arctic and Boreal Biota during the Quaternary Period; Cramer: New York, NY, USA, 1937.

27. Tolmachev, A.I. Fundamentals of Plant Habitat Theory: Introduction to Plant Community Chorology; State University Publishing: Leningrad, Russia, 1962.

28. Lavrinovich, M.V. Physical Geography of Eurasia (Regional Overview); Belarusian State University: Minsk, Belarusia, 2003. Available online: https://b-ok.cc/book/3128971/f9cd53 (accessed on July 2003). (In Russian) 
29. Rogers, P.C.; Pinno, B.D.; Šebesta, J.; Albrectsen, B.R.; Li, Q.; Ivanova, N.; Kusbach, A.; Kuuluvainen, T.; Landhäusser, S.M.; Liu, H.; et al. A global view of aspen: Conservation science for widespread keystone systems. Glob. Ecol. Conserv. 2020, 21, 00828. [CrossRef]

30. Usoltsev, V. Forest Arabesques, or Sketches of Our Trees' Life, 3rd ed.; Radomska Szkoła Wyższa w Radomiu: Radom, Poland, 2019.

31. Usoltsev, V.A. Forest Biomass and Primary Production Database for Eurasia: Digital Version, 3rd ed.; Ural State Forest Engineering University: Yekaterinburg, Russia, 2020. [CrossRef]

32. World Weather Maps. 2007. Available online: https://www.mapsofworld.com/referrals/weather/ (accessed on 15 June 2007).

33. Zubairov, B.; Heußner, K.-U.; Schröder, H. Searching for the best correlation between climate and tree rings in the Trans-Ili Alatau, Kazakhstan. Dendrobiology 2018, 79, 119-130. [CrossRef]

34. Morley, J.W.; Batt, R.D.; Pinsky, M.L. Marine assemblages respond rapidly to winter climate variability. Glob. Chang. Biol. 2016, 23, 2590-2601. [CrossRef] [PubMed]

35. Bijak, S. Tree-ring chronology of silver fir and ist dependence on climate of the Kaszubskie Lakeland (Northern Poland). Geochronometria 2010, 35, 91-94. [CrossRef]

36. Toromani, E.; Bojaxhi, F. Growth response of silver fir and Bosnian pine from Kosovo. South-East Eur. For. 2010, 1, 20-28. [CrossRef]

37. Emanuel, W.R.; Shugart, H.H.; Stevenson, M.P. Climatic change and the broad-scale distribution of terrestrial ecosystem complexes. Clim. Chang. 1985, 7, 29-43. [CrossRef]

38. Laing, J.; Binyamin, J. Climate change effect on winter temperature and precipitation of Yellowknife, Northwest Territories, Canada from 1943 to 2011. Am. J. Clim. Chang. 2013, 2, 275-283. [CrossRef]

39. Felton, A.; Nilsson, U.; Sonesson, J.; Felton, A.M.; Roberge, J.-M.; Ranius, T.; Ahlström, M.; Bergh, J.; Björkman, C.; Boberg, J.; et al. Replacing monocultures with mixed-species stands: Ecosystem service implications of two production forest alternatives in Sweden. Ambio 2016, 45, 124-139. [CrossRef]

40. Baskerville, G.L. Use of logarithmic regression in the estimation of plant biomass. Can. J. For. Res. 1972, 2, 9-53. [CrossRef]

41. Lapenis, A.; Shvidenko, A.; Shepaschenko, D.; Nilsson, S.; Aiyyer, A.R. Acclimation of Russian forests to recent changes in climate. Glob. Chang. Biol. 2005, 11, 2090-2102. [CrossRef]

42. Huang, J.; Tardif, J.C.; Bergeron, Y.; Denneler, B.; Berninger, F.; Girardin, M.P. Radial growth response of four dominant boreal tree species to climate along a latitudinal gradient in the eastern Canadian boreal forest. Glob. Chang. Biol. 2010, 16, 711-731. [CrossRef]

43. Givnish, T.J. Adaptive significance of evergreen vs. deciduous leaves: solving the triple paradox. Silva Fenn. 2002, 36, 703-743. [CrossRef]

44. Schaphoff, S.; Reyer, C.P.; Schepaschenko, D.; Gerten, D.; Shvidenko, A. Tamm Review: Observed and projected climate change impacts on Russia's forests and its carbon balance. For. Ecol. Manag. 2016, 361, 432-444. [CrossRef]

45. Spathelf, P.; Stanturf, J.; Kleine, M.; Jandl, R.; Chiatante, D.; Bölte, A. Adaptive measures: integrating adaptive forest management and forest landscape restoration. Ann. For. Sci. 2018, 75, 55. [CrossRef]

46. Vasseur, F.; Exposito-Alonso, M.; Ayala-Garay, O.J.; Wang, G.; Enquist, B.J.; Vile, D.; Violle, C.; Weigel, D. Adaptive diversification of growth allometry in the plant Arabidopsis thaliana. Proc. Natl. Acad. Sci. USA 2018, 115, 3416-3421. [CrossRef] [PubMed]

47. Anderegg, W.R.; Anderegg, L.D.L.; Kerr, K.L.; Trugman, A.T. Widespread drought-induced tree mortality at dry range edges indicates that climate stress exceeds species' compensating mechanisms. Glob. Chang. Biol. 2019, 25, 3793-3802. [CrossRef] [PubMed]

48. DeLeo, V.L.; Menge, D.N.L.; Hanks, E.M.; Juenger, T.E.; Lasky, J.R. Effects of two centuries of global environmental variation on phenology and physiology of Arabidopsis thaliana. Glob. Chang. Biol. 2019, 26, 523-538. [CrossRef]

49. Denney, D.A.; Anderson, J.T. Natural history collections document biological responses to climate change: A commentary on DeLeo et al.(2019), Effects of two centuries of global environmental variation on phenology and physiology of Arabidopsis thaliana. Glob. Chang. Biol. 2020, 26, 340-342. [CrossRef]

50. Bigot, S.; Buges, J.; Gilly, L.; Jacques, C.; Le Boulch, P.; Berger, M.; Delcros, P.; Domergue, J.-B.; Koehl, A.; Ley-Ngardigal, B.; et al. Pivotal roles of environmental sensing and signaling mechanisms in plant responses to climate change. Glob. Chang. Biol. 2018, 24, 5573-5589. [CrossRef] 
51. Shelford, V.E. Animal Communities in Temperate America: As Illustrated in the Chicago region: A Study in Animal Ecology; University of Chicago Press: Chicago, IL, USA, 1913.

52. Odum, E.P. Fundamentals of Ecology; Saunders: Philadelphia, PA, USA, 1971.

(C) 2020 by the authors. Licensee MDPI, Basel, Switzerland. This article is an open access article distributed under the terms and conditions of the Creative Commons Attribution (CC BY) license (http://creativecommons.org/licenses/by/4.0/). 